\title{
The Female Double
}

\author{
By Christina Stojanova \\ Spring 2015 Issue of KINEMA
}

\section{THE FEMALE DOUBLE: SUBJECTIVITY BETWEEN ALLEGORY, FACTICITY AND MARIVAUDAGE}

\author{
'What is mind? No matter. What is matter? Never mind' \\ George Berkeley (1685-1753)
}

It is certainly significant that in two subsequent years Cristian Mungiu's film, Beyond the Hills (Dupa dealuri, Romania-France-Belgium, 2012) - or BTH - and Abdellatif Kechiche's Blue Is the Warmest Colour (aka La vie d'Adèle, France-Belgium-Spain, 2013) - or BITWC - were nominated for the highest award at the Cannes film festival, which the latter did get, while Mungiu (who got the Palme D'Or in 2007 for his 4 Months, 3 weeks and 2 Days/4 luni, 3 saptamâni si 2 zile) had to settle for the Best Screenplay award. But even more remarkable is that the duos of principal actresses - the Romanians Cristina Flutur and Cosmina Stratan, and the French Léa Seydoux and Adèle Exarchopoulos - became recipients of the Best Actress award ex-aequo in 2012 and 2013, respectively. Such a rare jury decision, honouring the refined work of the actresses in creating the psychological and emotional dynamics of their protagonists, is certainly also a recognition of the directors' unorthodox handling of this dynamics on both narrative and stylistic level.

In a way, their profound knowledge of the female spiritual and physical world could be explained with the fact that both Mungiu and Kechiche were brought up in non-Western, intensely patriarchal environments (Romanian totalitarianism and Tunisian Muslim culture, respectively). And, as sensitive artists, have developed keen - and as C. G. Jung would say, compensatory - sympathy to all things feminine. Yet their films belong to the tradition of such celebrated works, featuring female couples in close relationship, bordering on or openly homosexual, and made by male directors, as Ingmar Bergman's Persona (Sweden, 1966), Karoly Makk's Another Way aka Two Women (Egymásra nézve aka Olelkezo tekintetek, Hungary, 1982) and David Lynch's Mulholland Dr. (France-USA, 2001).

These films transcend sensationalism and sex-ploitation, and foreground social and cultural mores, which contextualize, but also determine the nature of the relationship. The dynamics within these female couples could be defined in light of what linguist-philosopher Mikhail Bakhtin calls 'the dialogic territory of the dance of identity between mind and body, and self and the other,' or between subversive unconscious desire and the rational 'laws of human society' (qtd in Christine Ramsay, unpublished). The female protagonists in these films could indeed be seen as opposites, both physically and temperamentally, with one of them playing the more passive role of an agent provocateur or a catalyst for the active transformation of the other.

In light of the Cartesian assumption 'I think therefore I am,' privileging mind over body since the late sixteen hundreds, the heroines of these films embark on their quests in order to be able to also feel and thus be, and thus bridge the gaping split, opened by modernity between the rational and the emotional, the consciousness and the unconscious, between logos and eros. Liv Ullmann's Elizabeth Volger from Persona, for example a stunningly successful actress, who has come to fully identify with her worldly image, or persona - sinks into silence after realizing the devastating abyss, which separates her from her neglected feeling function. Having lost her ability for empathy, she is unable to handle her despondent teenage son's love for her, nor reciprocate her husband's devotion. And it is only thanks to her psychiatric nurse Alma (Bibi Andersson) that she retains her wholeness by retrieving the feeling aspect of her personality.

In the highly metaphorical world of Bergman's modernist cinema, however, it remains unclear whether Elizabeth and Alma are two separate personalities, who fall in love with each other and merge into one better self, so to speak, or whether Alma is Elizabeth's alter-ego, her repressed, shadow self, whom she is finally able to release and identify with, adopting Alma's open and nurturing nature. Moreover, Elizabeth and Alma could certainly be seen as a dual projection of their director's anima or of what C .G. Jung calls the feminine archetype - with its positive and its negative, constructive and destructive sides - which is present in every male psyche (as is the animus, or male, archetype present in every woman's psyche). Anima and animus 
thus help form the syzygy with the contra-sexual human psyche, predicating its wholeness and completeness. Such an interpretation has been recently corroborated by Liv Ullmann, who said in an interview that she, and not his male actors, was Bergman's alter-ego (The New Yorker, Dec 9, 2013, p31).

The female pairs in both Another Way and Mulholland Dr. - and, for that matter, those in BTH and BITWC - represent a type of doubling with wider socio-historical and political implications. Indeed, with the advent of the post WWII feminist movements, and under the transformational economic pressures of modernization, enforced by either Marxist-inspired, Soviet-type repressive regimes or by Western liberal democracies, women have acquired not only financial independence and agency, but also, as the multiplicity of their beings-in-theworld (in Heideggerian sense) suggest, have intensified their strife for authenticity, subjectivity and freedom through growing interaction with the here and now. Seen in light of Heideggerian philosophy, therefore, it is the representation - ingenuously laid-out and brilliantly enacted - of this interaction, which takes the heroines of these films into the realm of personal individuation and (if I may say so) into the world of the great cinematic art, to which their numerous awards testify.

Yet when their strife for authenticity entails an intensive political engagement, which trumps their personal homoerotic relationship - as is the case in Another Way - the film becomes prone to accusations of using women as 'devices of representation' and of 'directing attention to larger "universal" issues' which, as Anikó Imre has put it in her Identity Games (MIT, USA, 2009: 142), leads to 'allegorizing' the lesbian relationship. In Another Way such an universal issue that 'puts collective pressures on the nation' is the lack of freedom and the suppression of truth as part of the ubiquitous totalitarian repression (ibid). The controversial investigative journalist Éva - in the award-winning interpretation of the Polish actress Jadwiga JankowskaCielak (Best Actress, Cannes 1982) kindles the political and sexual maturing of her colleague Livia (Grayna Szapoowska), whom Éva tenderly entices into a forbidden love affair during the days of worse totalitarian repression in Hungary, following the national anti-communist uprising in 1956. After subjecting Makk's film to a 'feminist "strong reading" of desire,' however, Imre finds it insufficiently capable of 'transcend[ing] the strict allegorical straight jacket of national seriousness into which the lesbian relationship is forced' (Ibid).

In my view, however, the allegorization - or more precisely metaphorization of this relationship - is the more honest and adequate approach to the subject, undertaken by male and straight female directors (Imre subjects Deepa Mehta's 1996 Indo-Canadian film Fire to similar criticism of allegorization). Otherwise attempts at playing up what Imre, following Judith Mayne, calls 'homotextuality' - the uniquely queer specificity of 'lesbian disturbances of spectacle' (ibid) - could invariably expose the director to accusations of cultural appropriation, as BITWC - because of its overabundance of 'homotextuality' - was in a number of articles, published in the British newspaper The Guardian between Nov 12 and 15, 2013.

The compelling immersion of the heroines of Another Way within their immediate political realities opens up the film to a modernist reading as a political metaphor, told in Aesopian language, pretty much in the spirit of another very successful Hungarian film from that time, István Szabó's Oscar-winning Mephisto (1981), where the story of the rise and fall of a famous actor in Nazi Germany reads as a transparent allegory about the fate of the artist and artistic freedom under any totalitarian regime, including communism. From such a point of view, Livia could be seen as a symbol of the Hungarian national spirit, ensnared by the repressive communist regime, in its turn epitomized by her high-ranking military officer of a husband (Péter Andorai), while Éva - as her publications suggest - is the force, capable of freeing this spirit through the power of truth she is pursuing both in her subversive writings and in her transgressive sexual orientation.

Such a reading might well seem unbearably trite more than three decades after the film's release, and it is therefore understandable why, stripped off its immediate socio-political context, the lesbian relationship seems stilted and hijacked by '"universal" issues of national importance' (Imre, ibid). Yet it was this blurring of boundaries between official and personal body politics; between sexual and political repression - and not so much homophobic indignation - that made Another Way so explosively dangerous for its time and precipitated its ban across Eastern Europe, imposed directly by Kremlin In tune with the times - the early 1980s being a particularly bleak era in the post-war Eastern Europe - the film ends up in tragedy. Livia's jealous husband shoots her in the neck after learning about her affair - and Éva, after being rejected by the wheel-chair-confined and confused Livia, lets herself be killed in an attempt to cross illegally the Hungarian-Austrian border. 
Unfortunately, the modernist Aesopian language of Eastern European dissident cinema lost its artistic and political edge (sometimes to the point of incomprehensibility) with the disappearance of the socio-political context that had begotten it. It is then hardly surprising that post-communist cinema in general, and the New Romanian cinema in particular, has turned away from its metaphorical tropes in favour of realism or what I would call, following Heidegger, cinema of facticity, which expresses most adequately its characters' struggle for authenticity or for what Jung would call need for 'individuation' (Martin Heidegger, Being and Time, Harper \& Row, New York, 1962, online).

For Mungiu, Beyond the Hills is the second film in which - by meticulously observing the facticity of his heroines' daily routine - he reveals not only their characters, but also the time and place they live in by closely following what Heidegger calls the 'multiplicity' of their beings-in-the-world, 'illustrated by having to do with something, producing something, attending to something and looking after it, making use of something, giving something up and letting it go, undertaking, accomplishing, evincing, interrogating, considering, discussing, determining...' (Heidegger, ibid). There could hardly be a better visual translation of the being-in-the-world philosophy than Oleg Mutu's attentive, yet detached camera, which brilliantly captures the intricate relationship of the young heroines, caught in the process of dealing with a serious existential crisis.

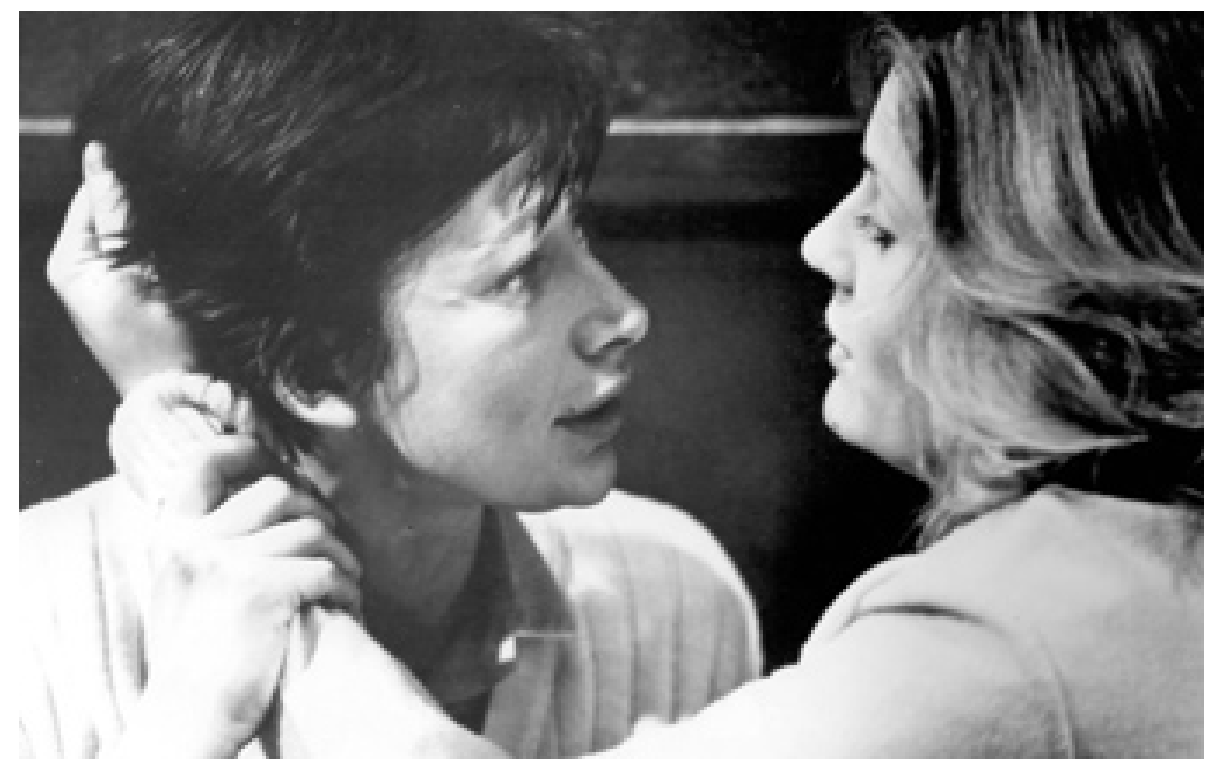

Figure 1: Another Way by Károly Makk (1982)

In 4 Months, 3 weeks and 2 Days, it is the arrangement of Gbia's clandestine abortion, which her student dorm room-mate Otilia (Anamaria Marinca) is self-sacrificially seeing through step by difficult step - finding money, booking a hotel room, bringing in the abortionist Dr Bebe (Vlad Ivanov), succumbing even to the abortionist's sexual blackmail, disposing of the foetus - despite the very real danger of being legally incriminated if caught. At the same time "Gbia (Laura Vasiliu) dwells in a stressed-out passivity, which lasts until her pregnancy is successfully terminated". Without even a hint of homo-eroticism, the two of them inhabit a traditional model of patriarchal coupledom, where the active, tom-boyish and tireless go-getter Otilia is paired with the timidly frail - or maybe cunningly 'feminine' - Gbia, for whom telling half-truths seems to be the only way of coping with, or rather manipulating, the crushing reality of Ceausescu's Romania in the late 1980s. The final episode however brings to a head Otilia's - and the viewer's - misgivings about Gbia's motifs, exposing her as the selfish opportunist she really is.

In Beyond the Hills Mungiu does hint upon a possible homo-erotic fling between Voichita (Cosmina Stratan) and Alina (Cristina Flutur), which seems to have brought them closely together during their early teenage years at the orphanage, but it only remains lurking in the psychological background of their relationship. Since $B T H$ situates its narrative between the opposite poles of what Nikolay Berdyaev, the famous Russian 
philosopher and self-proclaimed 'religious existentialist' calls the phenomenal and the noumenal, or the material and the spiritual, it is the emotional and temperamental differences between Alina and Voichita that are foregrounded. The general flow of their current lives is predetermined by major decisions they have taken a few years back, when the impulsive Alina left for Germany to seek freedom and the good life, and the down-to-earth Voichita joined a Romanian Orthodox nunnery. The film opens with the return of the emotionally broken Alina from what seems to have been a misfortune sojourn, and her seeking out Voichita in the hopes that the two of them could realize their teenage dreams and build a life together outside the nunnery. Voichita, who in the meantime has found in the monastic life and its structure the home she has craved for, invites her as a guest, but Alina's neurotic insistence that they both leave throws in disarray not only Voichita's daily routine, but also the allegiances of her newly-found faith.

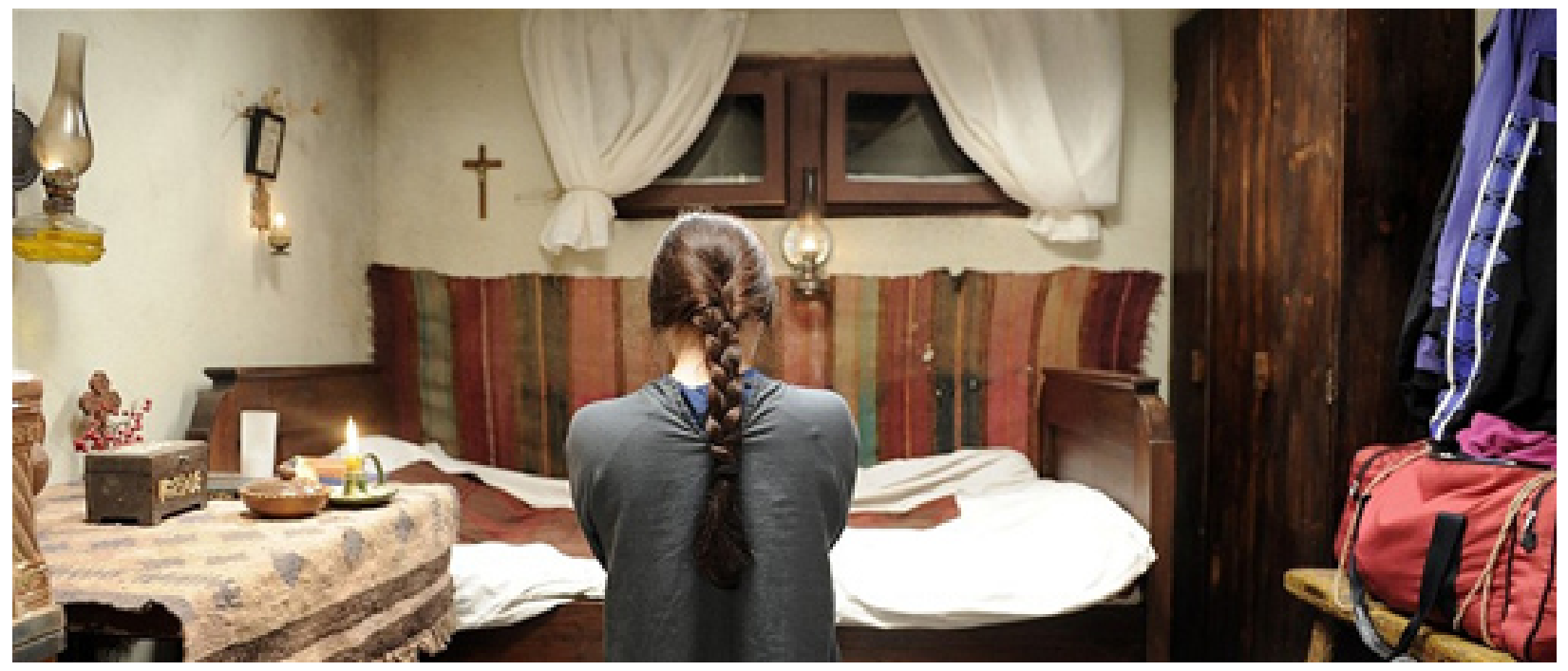

Figure 2: 4 Months 3 Weeks 2 Days by Cristian Mungiu

Once again Mungiu construes his narrative as a dynamic triangle, consisting of the female protagonists Voichita and Alina, and the Priest (Valeriu Andriuta), a male character who, like Dr Bebe, becomes the antagonist, whose peremptory actions ultimately determine the girls' fate. Mutu's camera meticulously follows the facticity of Voichita's beings-in-the-world as a nun and as Alina's friend (and possibly a former lover). Braving the snow and cold, she is perennially busy with never ending chores in and around the nunnery, where everyone works hard for their daily bread, but still finds time to check on Alina and try to pull her from the depression she is sinking into. Short of leaving the nunnery - an idea Voichita firmly rejects although it seems to be the only way to make Alina happy - she is tirelessly looking for ways to help her friend. First Vochita enlists the professional help of the local psychiatric ward but, repulsed by the primitive and heartless treatment Alina receives, brings her back to the nunnery. She then appeals to Alina's foster parents to take her back, and not only do her efforts fail, but in the process it becomes clear they have robbed Alina of a large sum of money. Finally, Voichita turns to the Priest, the nuns' spiritual leader, who reluctantly takes over as the principal decision-maker in the evolving drama.

What follows is a disturbingly realistic illustration of the banal dictum 'hell is paved with good intentions': the Priest decides to exorcise the increasingly erratic Alina from her demons, applying an ancient religious ritual, and takes a formal permission to do so from Alina's retarded brother and from Voichita. Like Otilia, Voichita has to take upon herself the fate of another - this time genuinely helpless - human being and ends up paying a high moral and probably legal price for it. On the third day of the rite, whose harrowing details the film follows scrupulously, Alina suddenly dies, and the Priest - along with the nuns who participated in the exorcising, including Voichita - are taken into custody.

Beyond the Hills, unlike 4,3,2, does not espouse a clear-cut moral dilemma and, despite attempts to see it alternatively as criticism of the Orthodox Church, or of Romanian post-communist society, it passes no judgement - moral or ideological - on either, yet offers an extremely detailed portrait of both. With the help 
of the inimitably realistic facticity of their film, Mungiu and Mutu take the viewers on a unique journey of Voichita's emotional and psychological beings-in-the-world, prompted by the need to reconcile her love for Alina with her stringent obligations of a nun. Stratan's Voichita is a petite and almost nondescript brunette, whose constant motility expresses articulately her fluid psychological states. As a near-perfect casting choice, Stratan's Voichita is well counter-balanced by Flutur's dark blonde, tall and handsomely built, but inert both physically and psychologically - Alina.

Voichita's emotional trajectory is determined by her empathy for Alina, which fluctuates between impatience, annoyance and guilt and is registered with remarkable sensitivity for minute psychological details. It is parallelled by the trajectory of her religious devotion, which moves through multiple shades of credulous piousness to outright scepticism, and then back again to devotion, this time around prompted not by faith alone, but by the conscientious recognition of her own guilt for Alina's tragic end, and by realization of the Priest's genuine, albeit terribly misguided efforts to help. Voichita's emergent subjectivity is signalled by her violation of the strict monastic code in the conclusive episode: dressed in Alina's beige turtleneck sweater and with uncovered head, she enters the police van voluntarily, as a mature person, who is ready to face the consequences of her own actions both as a friend and as a nun.

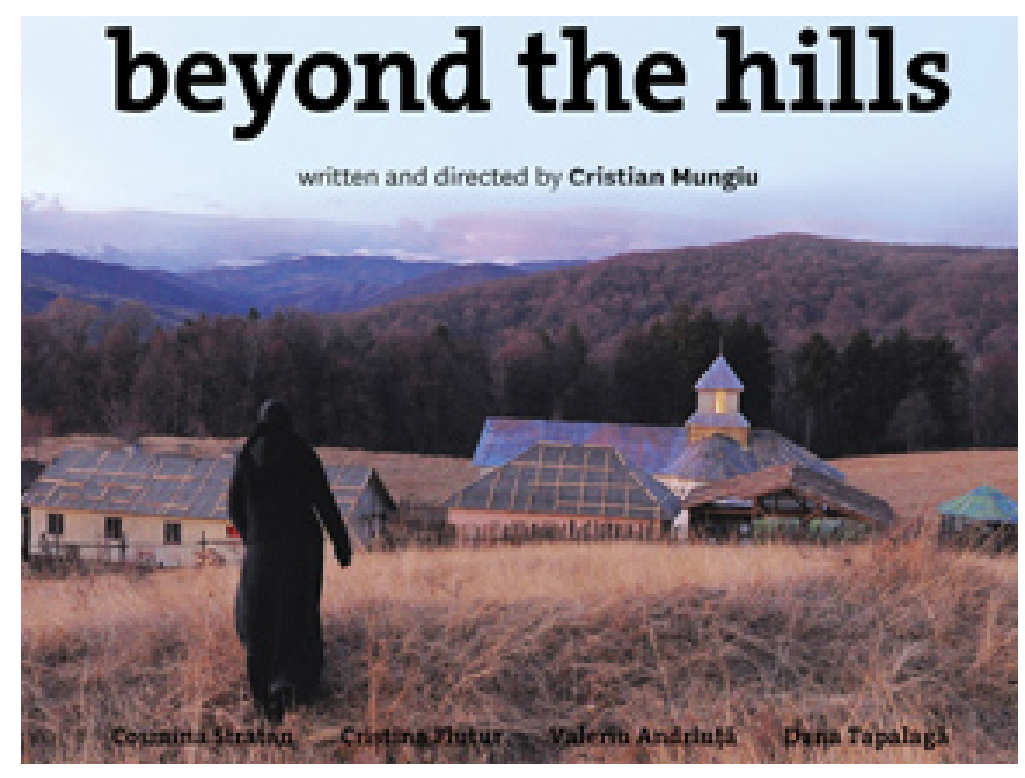

Figure 3: Beyond the Hills

Kechiche follows the emotional and psychological trajectory of Adèle in Blue Is the Warmest Colour in a similarly detailed fashion, influenced richly by what connoisseurs of French literature call marivaudage - a term coined either by Diderot and used by Voltaire as derogatory - with reference to the plays of the $17^{\text {th }}-18^{\text {th }}$ century French writer Pierre de Marivaux. His most famous (and unfinished) novel, La vie de Marianne (The Life of Marianne), whose eleven sections were published between 1731-1741(5), is recognized by Kechiche as the biggest influence on his film. This is despite the fact that the film is based on the 2010 French graphic novel Le bleu est une couleur chaude (Blue Is the Warmest Colour) by lesbian writer Julie Maroh - both explicitly, by naming it after Marivaux's original La vie d'Adèle - Chapitres 1 \&5 2/ (The Life of Adèle Chapters 1 \& 2), and implicitly, by adopting marivaudage as the film's style.

Kechiche, his cameraman Sofian El Fani and the two actresses have achieved that rare rapport between creators and characters, on one hand, and between characters and their zeitgeist, on the other. The result is a mixture of subtle metaphysics and bizarre trivialities, which constitute marivaudage, known also for its meticulous descriptions of characters, their environment, and their thoughts, conveyed either by the author or in a direct dialogue. It is not by chance that the film opens with a senior high-school class in French literature, where the students discuss La Vie de Marianne, and it is Adèle, the film's protagonist, who offers the most interesting comments. Thus Marivaux's classic sets the tone of the film, and defines Adèle 
as an original, romantic thinker, strikingly intelligent and emotionally mature for her age. Being her own person, Adèle is pretty much defined by her declared interest in 'thick books,' which accounts for her specific 'coolness,' along with her great looks - for her popularity among her classmates, both male and female. With a mixture of Heideggerian 'facticity' and marivaudage, the film then follows faithfully Adèle's evolution into adulthood over a period of about five years or so.

Early on in the film, Adèle's uniqueness is further emphasized by implications of her different sexual orientation, which explains the disappointing intimate encounter with a boy from her school, a passionate kiss she shares with a cheeky female peer, and culminates in her faithful encounter with Emma - an older fine arts student with blue hair - whom she once casually glimpses in the street and then meets in a gay bar. The intensity of their relationship becomes shockingly explicit in the two sex scenes, which last longer than any such scenes have before outside pornographic cinema.

The film's detractors, as mentioned above, as well as its superficial admirers, tend to play up the sensationalist effect of these scenes. Within the context of the three-hour-long narrative, however, the sex scenes acquire the numinous intensity that distinguishes everything Adèle does. El Fani's camera, lingering lovingly on Exarchopoulos' superbly expressive face, captures Adèle's voracious appetite for love and life, which does culminate in the sex scenes, but also comes forcefully in her eating, cooking, dressing up, socializing. And above all, distinguishes her teaching, which occupies much more screen time than any other activity, thus emphasizing her charmingly genuine ways with kids as well as her accomplished personality.

Initially, Emma is blown off her feet by Adèle's romantic spontaneity and spiritual depths, but as they move in to live together and the initial enchantment wanes, the couple settles in the (stereo)typically bourgeois roles of Emma, the Artist, who does the painting and the intellectual socializing, while the socially inferior Adèle becomes her domesticated partner, who does the cooking, the admiring and the listening. Increasingly unable to integrate Adèle's emotional intensity within her daily life, Emma begins to avoid sex with Adèle, all the more that she is in the process of renewing her affair with Lise (Mona Walravens), a fellow artist, who is now pregnant, and is both socially and professionally the more attractive companion for Emma.

This turn of events immensely upsets Adèle, for whom love and sex with Emma is a profoundly spiritual experience, and she tries to find solace in a clandestine fling with a (male) colleague of hers. When Emma finds this out, she is a bit too quick to throw Adèle out in a humiliating scene. Contrary to viewers' expectations, however, despite of her unbearable pain, Adèle goes on with her life, throwing herself even more passionately into teaching. In the last episode, set a few years after Adèle's painful rite of passage into adulthood, she emerges as a beautiful and mature, albeit somewhat withdrawn young woman, ennobled by the traumatic experience.

In fact, Beyond the Hills and Blue Is the Warmest Colour are treatises on the coming-of-age drama of two extraordinary young women. Thus on one level, their relationships could be seen as probings into the emotional, sexual and spiritual limits of a female bonding. Following Bakhtin, each of these pairs could also be seen as engaged in 'the dance' of contemporary female identity, engendered by the internal frictions between 'subversive unconscious desires' and the 'rational laws of human society,' on one hand, and on the other - by the externalized battles between self and the other.

And what is even more intriguing, $B T H$ and $B I T W C$ not only come through uncannily as doubling on one another on the thematic, stylistic and philosophical levels, but also in deploying strategies for attracting the viewer's attention to serious issues plaguing our post-modern world. In BITWC, it is the sex-scenes which, in a way of a show-stopper, open a royal road to exploring the integrity of mind and body, the phenomenal and the noumenal, the spiritual and the material. In $B T H$, on the other hand, it is the exorcising rites the contrasting opposite of the metaphysically orgiastic sex - which point to the severity of emotional and spiritual needs that tear at the fragile veneer of rationality and scientific progress.

Among other things, the comparison between the two films bespeaks about urgent social issue like the uneven distribution of wealth in the New Europe. Indeed, the cold colours Mutu uses to portray the hard life in a snow-bound Romanian nunnery, where Voichita and Alina face constant challenges not only to their human integrity, but also to their physical survival, might as well be painting a life on another planet And it is just a couple of thousand kilometres to the North-West, in Lille, where Adèle and Emma deal with their existential 


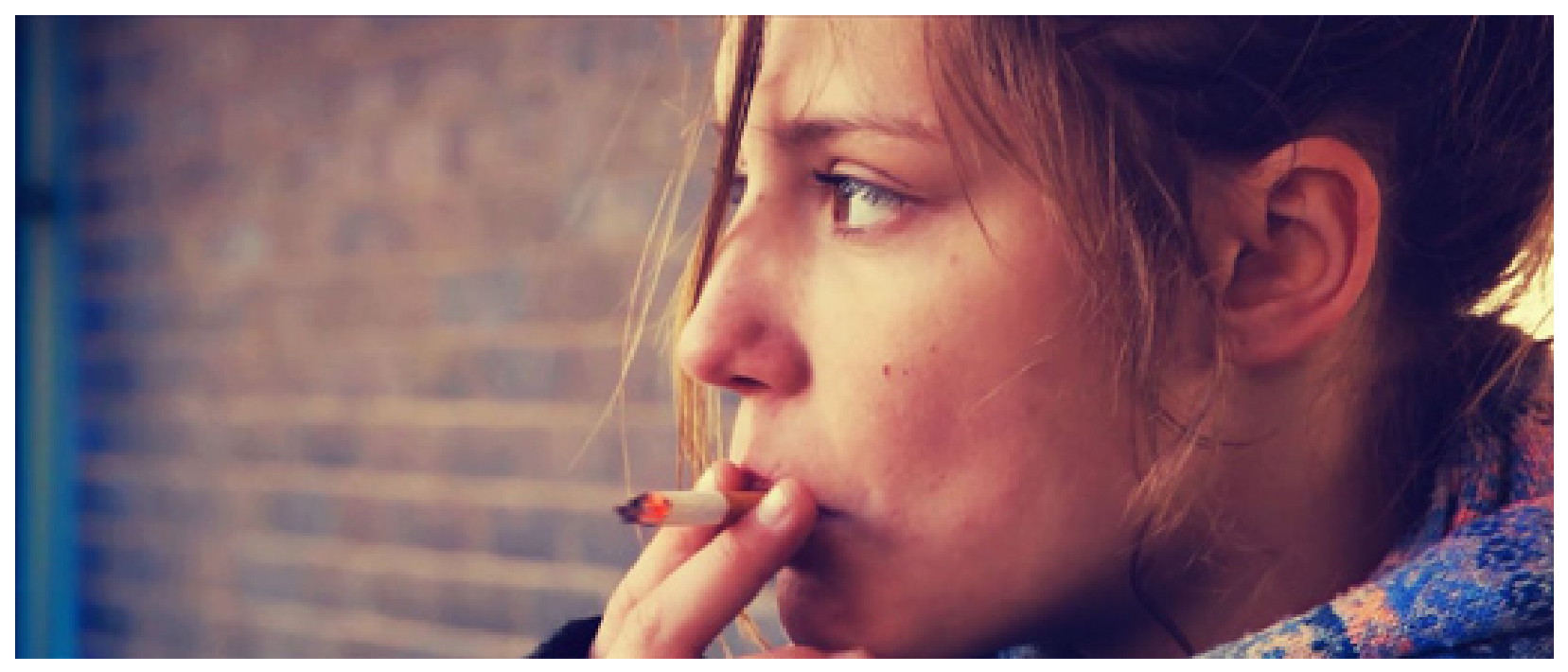

Figure 4: Blue Is the Warmest Colour by Abdellatif Kechiche

problems amidst a comfortable middle-class milieu, and where El Fani's bright colour palette succeeds in turning even blue into a warm colour, literally Yet despite the glaringly cruel irony of such a reductive interpretation, each film does complement the other in revealing a contrasting side of female existence in the modern Western world: one mired in poverty, abuse and repression, including sexual, and the other steeped in material plenitude and hedonism. And yet there is a link that connects Voichita and Adèle, and it is not only their strife for authenticity and integrity.

Thanks to the ingenuous mixture of aesthetics and philosophy - rigorously realistic Heideggerian facticity and visually indulgent Marivaudage, respectively - the passionate humanism and spirituality of Voichita and Adèle transcend the otherwise indispensable Marxist, feminist, queer and existentialist attempts to explain their motifs away with social and psychological arguments. For it is this surplus beyond the 'cogito,' imponderable and unexplainable, that has allowed Beyond the Hills and Blue Is the Warmest Colour to join the scantly populated pantheon of great cinematic works that speak forcefully about their life and times, and also to our souls.

\section{Reports}

Photo credits: 4 Months, 3 Weeks, 2 Days and Another Way: Mobra Films; Blue Is the Warmest Colour: Wild Bunch.

\section{Author Information}

Christina STOJANOVA teaches at the Department of Media Production and Studies at the University of Regina, Canada. She has contributed to Cine-bulles, KinoKultura, and the Montreal Gazette. Her publications include chapters in Berlin Culturescapes, Making it Like a Man: Canadian Masculinities, Eastern European Cinema, Traditions in World Cinema, Horror International, Alternative Europe and Cinema and Globalization. 


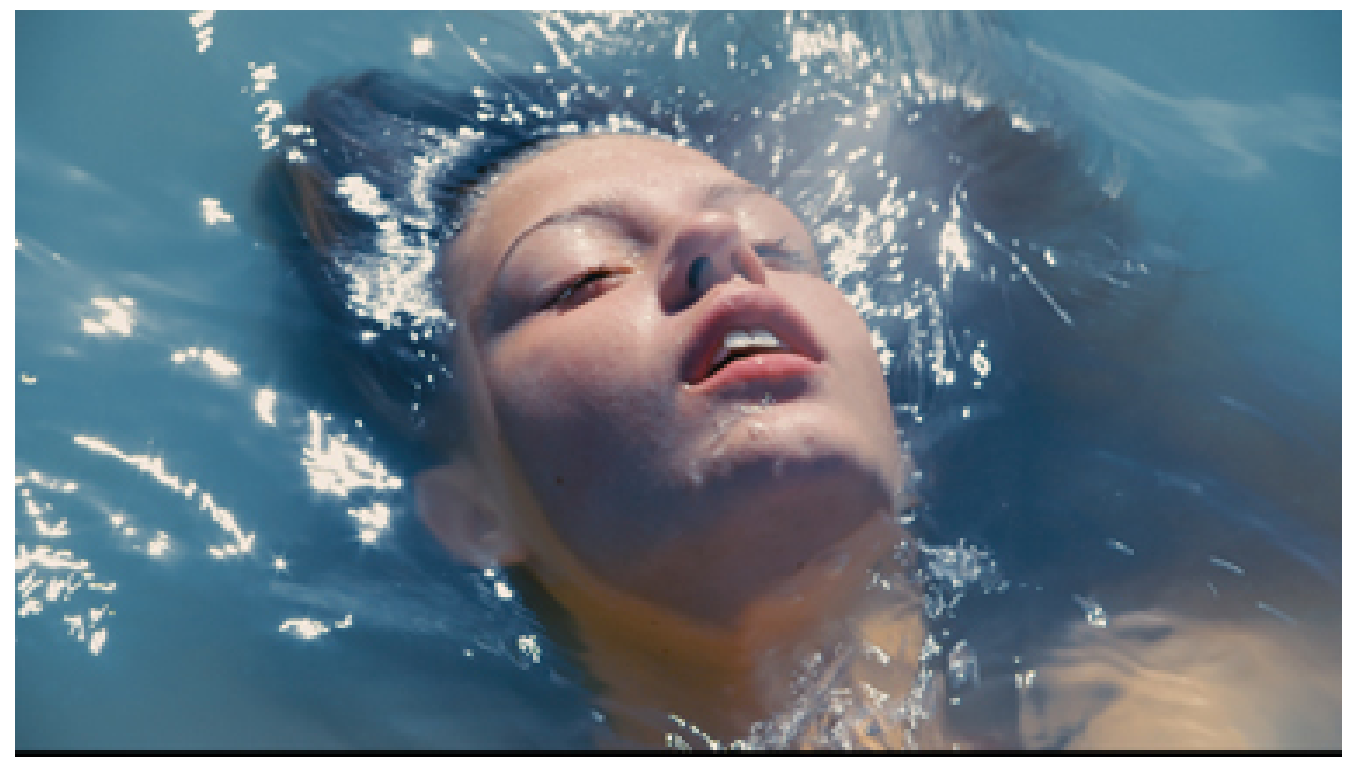

Figure 5: Blue Is the Warmest Colour by Abdellatif Kechiche 